Portland State University

PDXScholar

1974

\title{
An Investigation of Infection Mechanisms of Arceuthobium Campylopodum
}

Annabella Jaramillo Garcia

Portland State University

Follow this and additional works at: https://pdxscholar.library.pdx.edu/open_access_etds

Part of the Biology Commons

Let us know how access to this document benefits you.

\section{Recommended Citation}

Garcia, Annabella Jaramillo, "An Investigation of Infection Mechanisms of Arceuthobium Campylopodum" (1974). Dissertations and Theses. Paper 2177.

https://doi.org/10.15760/etd.2174

This Thesis is brought to you for free and open access. It has been accepted for inclusion in Dissertations and Theses by an authorized administrator of PDXScholar. For more information, please contact pdxscholar@pdx.edu. 
AN ABSTRACT OF THE THESIS OF Annabella Jaramillo Garcia for the Master of Science in Biology presented July 25, 1974.

Title: An Investigation of Infection Mechanisms of Arceuthobium campy lopodum.

APPROVED BY MEMBERS OF THE THESIS COMMITTFF.
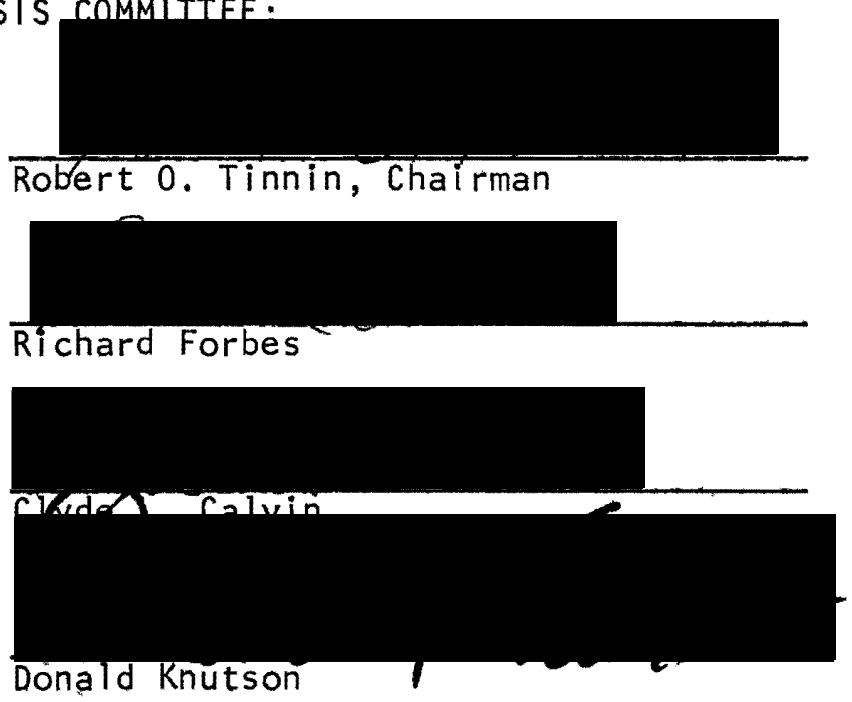

Wound periderm is formed by Juniperus occidentalis and Calocedrus decurrens in resistance to infection by the dwarf mistletoe Arceuthobium campylopodum. The pattern of wound periderm formation suggests that chemical as well as mechanical factors are involved. The concentration of hydrolases in the radicular apex of the parasite suggests that they may facilitate the penetration process by which dwarf mistletoes infect their hosts. Emzymatic assistance may also provide a partial explanation for the specificity with which dwarf mistletoes are adapted to given hosts. These resistance responses by the non-host species were compared with the normal infection process on Pinus ponderosa. 
TO THE OFFICE OF GRADUATE STUDIES:

The members of the Committee approve the thesis of Annabella Jaramillo Garcia presented July 25, 1974.

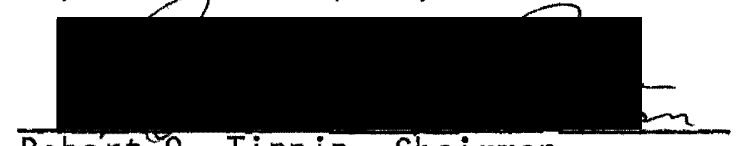

Robert 0 . Tinnin, Chairman

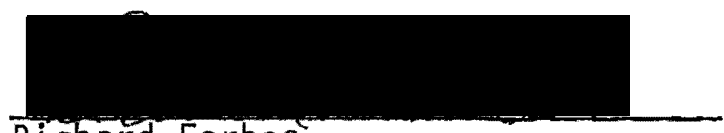

Richard Forbes

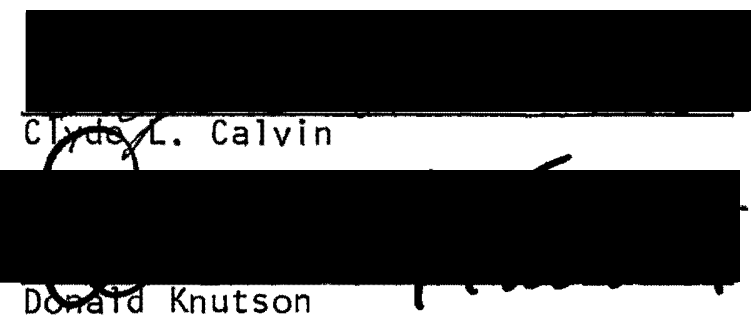

APPROVED:

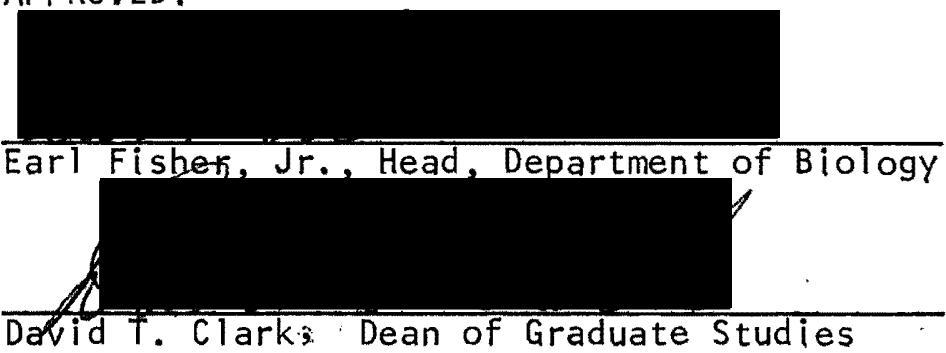

July 25,1974 
AN INVESTIGATION OF INFECTION MECHANISMS OF

ARCEUTHOBIUM CAMPYLOPODUM

by

ANNABELLA JARAMILLO GARCIA

A thesis submitted in partial fulfillment of the requirements for the degree of

MASTER OF SCIENCE

in

BIOLOGY

Portland State University

1974 


\section{ACKNOWLEDGEMENTS}

In conducting this study and in preparation of this manuscript, I gratefully acknowledge the advice and assistance given me by Dr. R. 0 . Tinnin; criticism offered me by Drs. R. Forbes, C. L. Calvin, and D. M. Knutson; and financial assistance extended me by The collins Foundation, the U. S. Forest Service, and Dr. Earl Fisher, Jr. and the Biology Department, Portland State University. 
ACKNOWLEDGEMENTS . . . . . . . . . . . . . . . . . . . . . . . i i i LIST OF FIGURES . . . . . . . . . . . . . . . . . . . . . . V

INTRODUCTION . . . . . . . . . . . . . . . . . . . . . . 1
MATERIAL AND METHODS. . . . . . . . . . . . . . . . . . . . . . . . . . . . . . . . . . . . . . . . . . . . . . . . . . . . . . . . . . . . . . . . . . . . . . . . . . . . . . . . . . . . . . . . . . . . . . . . 13
RESULTS 14
DISCUSSION 


\section{LIST OF FIGURES}

FIGURES

PAGE

1 Diagram of Juniperus occidentalis wi th Arceuthobium campylopodum: Orientation of mistletoe to host. $100 x$..................... 6

- 2 Juniperus occidental is with Arceuthobium campylopodum

illustrating reaction to presence of parasite. 100x.. 6

3 View of uninfected Juniperus occidentalis $100 \mathrm{X}$. . . . 6

4 View of penetration of Pinus ponderosa by Arceuthobium campylopodum. $100 x$............... 7

5 View of uninfected Pinus ponderosa. 100x . . . . . 7

$6 \quad$ Calocedrus decurrens with Arceuthobium campylopodum

illustrating reaction to presence of parasite, 100X . . 9

7 Calocedrus decurrens wi th Arceuthobium campylopodum.

illustrating reaction to presence of parasite. 100X . 9 9

8 Diagram of mistletoe radicle showing location of

hydrolases in parasite tissue .......... 10 


\section{INTRODUCTION}

Arceuthobium cámpylopodum Engelm. (western dwarf mistletoe;

Viscaceae), is a parasitic flowering plant having Pinus ponderosa Dougl. (ponderosa pine), $\underline{P}$. jeffreyi Grev. \& Balf. (jeffrey pine), and $\underline{P}$. attenuata Lemm. (knobcone pine) as principle hosts (Hawksworth and Weins, 1972).

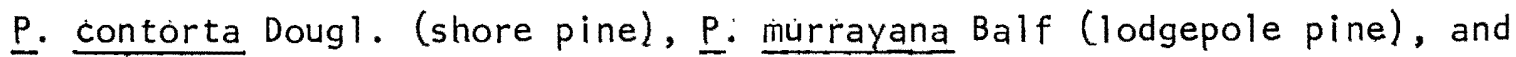
P. sylvestris L. (scotch pinel are also susceptible to infection particularly when they are associated with the principle hosts (Hawksworth and Weins, 1972).

Dwarf mistletoe spreads by the forceful ejection of seeds from the fruits. The seeds are coated with a sticky viscous material and will adhere to any dry surface which they may strike (Kuijt, 1960). When the seeds stick to the needles of a host, they will slide down the needles during periods of rain and eventually make contact with the host branch. As these seeds germinate, the radicle elongates until it contacts the host branch and holdfast development is initiated (Kuijt, 1960; Hawksworth, 1961; Scharpf, 1967). The parasite slowly penetrates the host tissues, by a poorly understood process until infection is finally realized. On a non-host species, radicle development occurs in the same manner. A holdfast develops but complete penetration and infection do not occur, suggesting that host specificity is determined, at least in part, at the time of penetration. East of the Cascade Range in Oregon, Juniperus occidentalis Hook (western juniper) often grows intermixed with $\underline{P}$. ponderosa. One such 
area exists on the north slope of the Maury Mountains in the Ochoco National Forest near Sherwood Creek. At this site $\underline{P}$ : ponderosa is heavily infected, yet the $\lrcorner$. occidentalis examined showed no sign of infection even though the limbs bore numerous germinated seeds of $\underline{A}$. campylopodum having radicles with developing holdfasts. Because of the apparent immunity of $\underline{J}$. occidentalis to $\underline{A}$. campylopodum, I chose to compare radicle and holdfast development of $\underline{A}$. campylopodum on $\underline{\mathrm{J}}$. occidentalis with that on P. ponderosa.

1 also investigated the possibility of enzymatic action in the penetration process (A. campylopodum into $\underline{P}$. ponderosa). Several workers have suggested that enzymes are involved in the infection mechanisms of other plant pathogens (McClendon, et al., 1960; Flentje, 1959; Bateman and Millar, 1966; and Agrios, 1969) and vascular parasites (Pieh1, 1963). The possibility of enzymatic action in the penetration process of $\underline{A}$. campylopodum has been dismissed by Weir (1916) and Scharpf (1967), but 1 believe the question should be reexamined since enzymatic modification of either the middle lamella or cell wall could reduce mechanical resistance to penetration. 


\section{MATERIALS AND METHODS}

Cuttings of naturally inoculated Pinus ponderosa and Juniperus occidentalis were collected in the spring, summer and fall of 1972 from a study site along Sherwood Creek Road just inside the National Forest Boundary (TI7S; RI9E). The cuttings were fixed in $40 \%$ formalin-propionic acid-50\% ethanol $(10: 5: 85$ by volume), dehydrated in tertiary butyl alcohol, embedded in paraplast containing DMSO and sectioned at 12 microns. Sections were stained with safranin-fast green (Sass, 1958) and mounted in Harleco synthetic resin.

In the laboratory seedlings of $\underline{\mu}$. occidentalis and $\underline{P}$. 'ponderosa were inoculated with pregerminated seeds of $A$. campylopodum, according to the methods of Knutson (1973). These artificially inoculated seedlings were cut and prepared as above at two months, four months, and six months after inoculation.

The cell wall and middle lamella of plant tissue are comprised in part of cellulose and pectic substances; hydrolases are the major group of enzymes most likely to degrade such materials. In order to demonstrate the presence of an enzyme of this type, a method must be used which not only detects the enzyme, but also prohibits migration of the enzyme from its active site. Using the procedure stated by Holt and Withers (1958), not only is the presence of the enzyme made apparent, but enzymatic migration is restricted to within 2.5 microns radial movement. For enzyme analysis, six 3 year old $\underline{P}$. ponderosa trees were each inoculated with five pregerminated seeds of $\underline{A}$. campylopodum. "Infected" tissue 
was cut at two, four, ten, twelve and slxteen weeks following inoculation, and kept frozen at $0^{\circ} \mathrm{C}$ for 48 hours in calcium-formol (Baker, 1946). The tissues were sectioned in a cryostat or by hand and placed in an incubation medium containing a substrate solution of 5-bromo-4chloroindoxyl acetate in $100 \%$ ethanol for 24 hours. The tissues were washed in $30 \%$ ethanol-glacial acetic acid (1000:1 by volume) for five minutes to stop the chemical reaction. The sections were transferred to gelatinized slides, dehydrated in a series of alcohol concentrations, cleared with xylene, and mounted in Harleco synthetic resin. A Zeiss Standard Universal Microscope was used for microscopic examination of the mounted sections. 


\section{RESULTS}

I observed mistletoe radicles with developing holdfasts on cuttings of $\underline{J}$. occidentalis and $\underline{P}$. ponderosa collected from the study site.

On $\mathrm{J}$. occidentalis the radicles had grown under the scale leaves, while on $\underline{P}$. ponderosa they were located in the axils of needle fascicles or along the stem.

In serial sections of inoculated $\underline{J}$ : occidentalis and $\underline{P}$. ponderosa heavy meristematic activity in the radicular apex of the parasite (Fig. $1,2,4$ ) and a visible zone of collapsed cells within the holdfast (Fig. 1, 4) indicated that the penetration process (Scharpf, 1967) was underway. In $\mathrm{J}$. occidentalis a zone of necrotic but uncrushed tissue surrounded the penetrating structure of the parasite. The necrotic zone was restricted by an orderly arrangement of cells with secondary walls, typical of periderm, which the parasite presumably initiated. (Fig. 2). This periderm was observed in samples taken two months following inoculation. Samples taken from infection of greater age suggested that the periderm restricts the penetration of the dwarf mistletoe radicle to peripheral host tissues. In sections of uninoculated $\underline{J}$. occidentalis peridermal and necrotic tissue were absent (Fig. 3). In sections of P. ponderosa the dwarf mistletoe had penetrated the epidermis (Fig. 4) but there was no evidence of tissue necrosis. Typical peridermal tissue (Esau 1960, 1965) was observed in both infected and uninfected tissue (Fig. 4, 5). For the sake of comparison, and because it grows intermixed 
Figure 1-3. 1. Diagram of a longitudinal section of Juniperus occidentalis with Arceuthobium campylopodum illustrating orientation of mistletoe to host. 2. Longitudinal section of $\underline{\jmath}$. occidentalis with $A$. campylopodum illustrating reaction to presence of parasite. 100X. 3. Longitudinal section of uninfected tissue of $\mathrm{J}$. occidentalis. 100x. H-host tree tissue; DM-parasite holdfast; cl-collapsed layer of cells within the holdfast; m-meristematic zone of penetration structure; n-necrotic host tissue; wp-wound periderm tissue of host. 

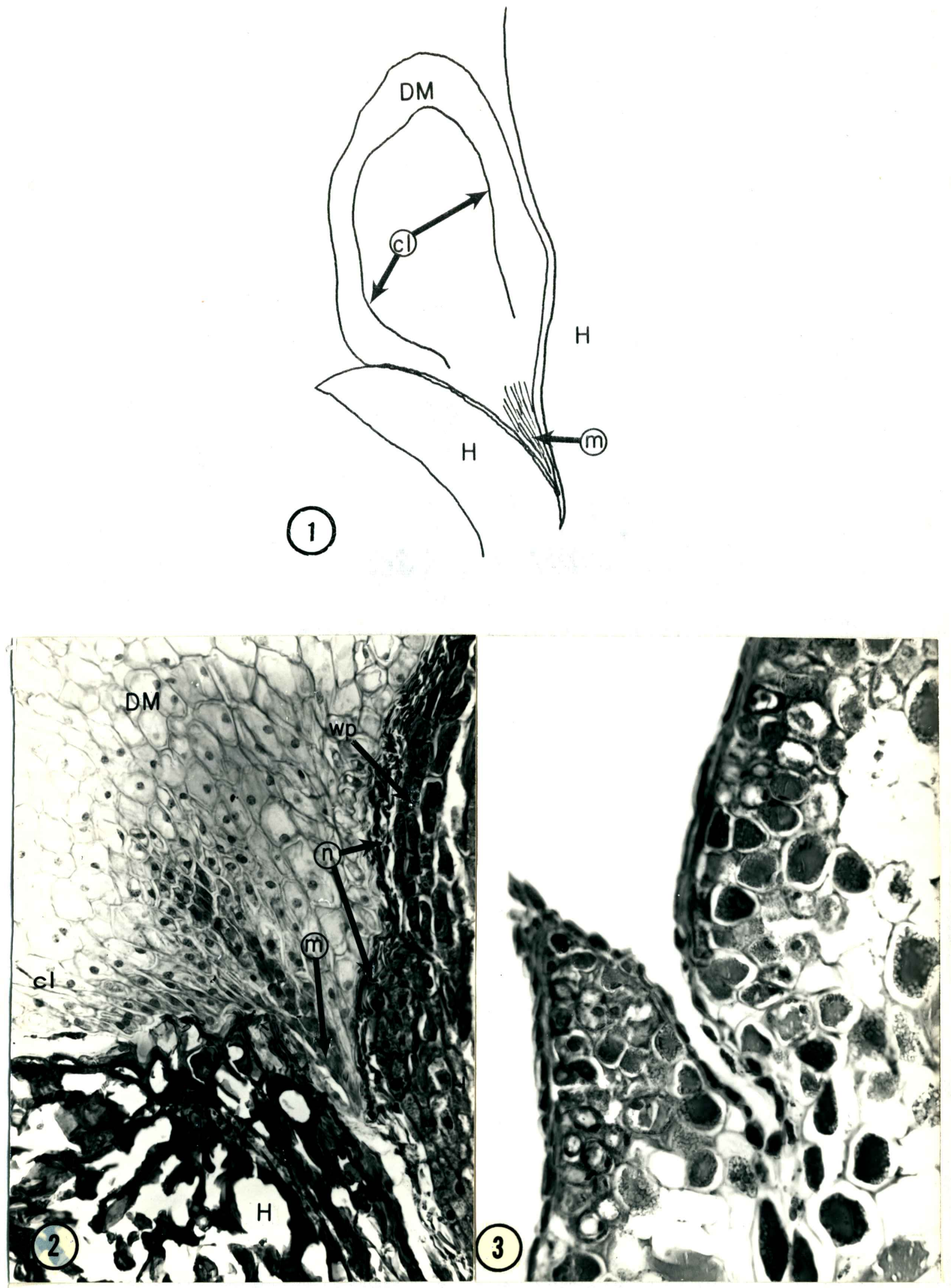
Figure 4-5. 4. Longitudinal section of pinus ponderosa with Arceuthobium campylopodum. View illustrates penetration of host by the parasite. 100x. 5. Longitudinal section of uninfected $\underline{P}$. ponderosa. H-host tree tissue; DM-parasite holdfast; cl-collapsed layer of cells within the holdfast; m-meristematic zone of penetration structure; p-normal periderm. 


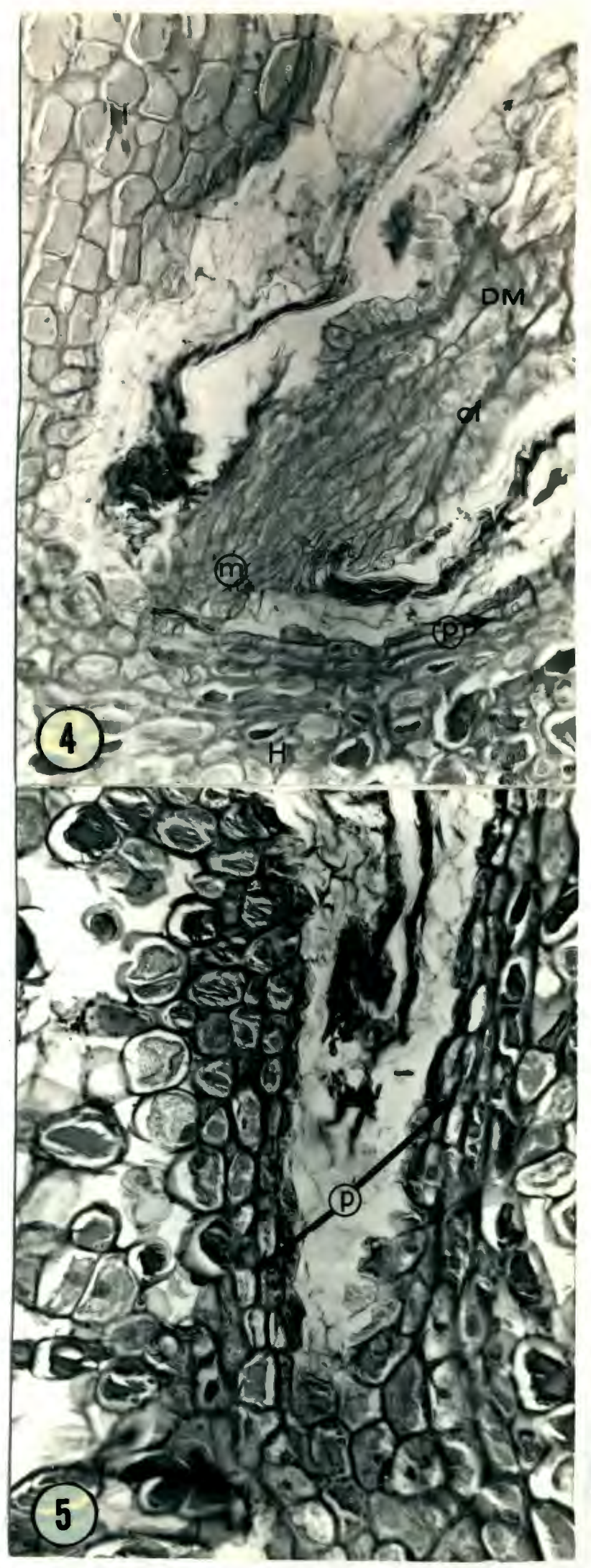


with infected $\underline{P}$. ponderosa at various sites in Oregon, I obtained four seedlings of Calocedrus decurrens (incense cedar) which were artificially inoculated with $\underline{A}$. campylopodum sixteen weeks prior to sectioning. Sections were prepared in the same manner as those of $\underline{J}$. occidentalis. Subsequent examination showed necrotic tissue adjacent to the penetrating parasite (Fig. 6) similar to that seen in J. occidentalis. The necrotic tissue was also bounded by a peridermal tissue (Fig. 6, 7). In freehand and frozen sections of inoculated $\underline{P}$. ponderosa (two weeks after inoculation) hydrolases were detected in the meristematic region of the radicular apex of the parasite. In sections of pine, sixteen weeks after inoculation, hydrolase concentrations were heaviest. in the area where the penetration structure had begun to form. When examining sections of mistletoe radicles I observed that hydrolases were heavily concentrated within one millimeter of the radicular apex and were also in the vascular tissue of the developing radicle (Fig. 8). They were also seen in the xylem rays of the host tissue. 

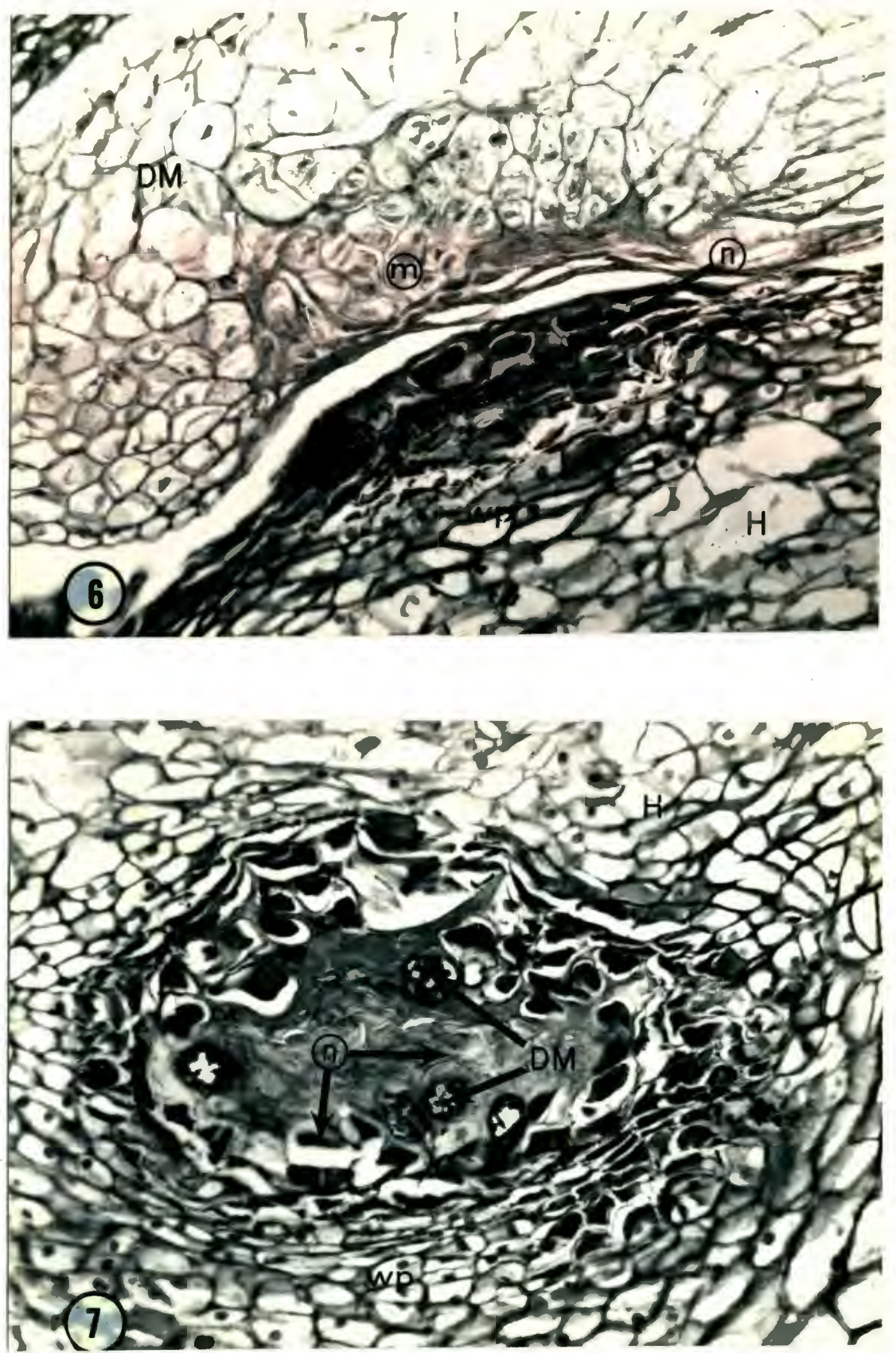


\section{DISCUSSION}

A. campylopodum seeds will germinate and form radicles with holdfasts on many substrates. Although $\underline{\mathrm{J}}$. occidentalis and $\underline{\mathrm{C}}$. decurrens grow intermixed with $\underline{P}$. ponderosa in some areas heavily infected with A. campylopodum, they are resistant to infection by dwarf mistletoes. I have observed that wound periderm formation in $\underline{J}$ occidentalis and C. decurrens is a mechanism of resistance to parasitization. Wound periderm formation is also correlated with the resistance of Larix larcina (eastern larch) and Pinus banksiana (Jack pine) to Arceuthobium pusilum (Tainter, 1970; Tainter and French, 1971) and some species of Abies to A. ablentinum (Scharpf, 1967). In J. occldentalis and $\underline{C}$. decurrens the broad zone of necrotic, uncrushed tissues restricted by wound periderm suggests that in addition to mechanical pressure (Scharpf, 1967), chemical factors facilitate the infection process of dwarf mistletoes. Similar observations have been made in the closely related mistletoe, Viscum album (Thoday, 1951). Among the chemicals which may be important are hydrolases which are thought to function in normal radicle growth, in the synthesis of cellulose (Barber, et al., 1964; Roberts and Butt, 1967); however, they may in the case of dwarf mistletoes, facilitate penetration of host tissues by the degradation of intercellular materials, as they appear to in many other pathogens. This hypothesis gains some support from the observation that correlated with the concentration of hydrolases in the immediate vicinity of the radicular apex of the dwarf 
mistletoe, is the necrosis of adjacent host tissue. If chemicals are involved in the infection process of dwarf mistletoes, a possible explanation for host specificity exists. A highly specific combination of chemicals could explain facilitation of penetration of $\underline{P}$. ponderosa on one hand and initiation of the immune response exhibited by $\underline{J}$. occidentalis and $\underline{C}$. decurrens on the other. 


\section{CONCLUSIONS}

The increasing concern with dwarf mistletoes as destructive parasites on commercially important forest trees has led to expanded interest in the biology of these parasites. I have investigated the process by which the dwarf mistletoe $\underline{A}$. campylopodum, infects its host P. ponderosa. Of specific interest was the mechanism which prescribes the specificity that this parasite displays for a restricted number of species in the genus Pinus. I feel that both mechanical and chemical factors are involved in the infection process. Whatever the exact nature of the infection mechanism, it stimulates, in $\mathrm{J}$. occidentalis and $\underline{C}$. decurrens, the formation of a wound periderm in association with necrotic tissue. These resistance responses limit the number of species which can be utilized as hosts by $A$. campylopodum. Such responses are very probably the result of mismatched physiologic parameters between the parasite and the potential host. 


\section{REFERENCES CITED}

Agrios, George N. 1969. Plant Pathology. Academic Press, New York, N.Y.

Baker, J. R. 1946. The histochemical recognition of 1 ipine. Quart. J. Microscop. Sci. 87:441-471.

Barber, George A., A. D. Elbein and W. Z. Hassid. 1964. The synthesis of cellulose by enzyme systems from higher plants. ‥ Blol. Chem. 239:4056-4061.

Bateman, Durward F. and Roy L. Millar. 1966. Pectic enzymes in tissue degradation. Ann. Rev. Phytopathol. 4:119-146.

Esau, Katherine. 1960. Anatomy of seed Plants. John Wiley and Sons, New York.

1965. Plant Anatomy. John Wiley and Sons Inc., New York.

Flentje, N. T. 1959. The physiology of penetration and infection. Pages 76-87 in C. S. Holton, G. W. Fischer, R. W. Fulton, Helen Hart and S. E. A. McCallan, eds. Plant Pathology Problems and Progress 1908-1958. University of Wisconsin Press, Madison, Wisc.

Hawksworth, Frank G. 1961. Dwarf mistletoe of ponderosa pine in the Southwest. USDA.FS Tech. Bull. No: 1246.

and Delbert Wiens. 1972. Biology and classification of dwarf mistletoes (Arceuthobium). USDA-FS Agriculture Handbook No. 401.

Holt, S. J. and F. J. Withers. 1958. Studies in enzyme cytochemistry. V. An appraisal of indigogenic reactions for esterase localization. Proc. Roy. Soc. London. Ser B 148:520-534.

Kuijt, Job. 1960. Morphological aspects of parasitism in the dwarf mistletoes (Arceuthobium). Univ. Calif. Pub. in Bot. 30:337-436.

Knutson, D. M. 1973. Infection techniques and seedling response to dwarf mistletoe. Plant Dis. Rep. 58:235-238.

McClendon, John H., G. Fred Somers, and J. W. Heuberger. 1960. The occurrence of a variety of enzymes hydrolysing cell wall polysaccharides in apples rotted by Botryosphaeria ribis. Phytopathology. 1:258-261. 
Piehl, Martin A. 1963. Mode of attachment, haustorium structure, and hosts of Pedicularis canadensis. Amer. J. Bot. 50:978-985.

Roberts, R. M. and V.S. Butt. 1967. Patterns of cellulose-synthesis in Maize root-tips. Exp. Cell Research. 46:495-510.

Sass, John E. 1958. Botanical microtechnique. Iowa State University Press, Ames, lowa.

Scharpf, R. F. 1967. The biology and pathology of dwarf mistletoe Arceuthobium campylopodum $f$. abientinum parasitizing true firs (Abies spp.) in California. USDA.FS Tech. Bull. 1362.

Tainter, F. H. 1970. Wound periderm formation in Larix larcina in response to Arceuthobium pusilum. Phytopathology. 60:555-556.

and D. W. French. 1971. The role of wound periderm in the resistance of eastern larch and jack pine to dwarf mistletoe. Can. J. Bot. 49:501-504.

Thoday, D. 1951. The haustorial system of Viscum album L. J. Exp. Bot. 2:1-19.

Weir, J.R. 1916. Mistletoe injury to conifers in the Northwest. USDA Bul1. 360 . 
Figure 6-7. 6. Cross-section of Calocedrus decurrens with Arceuthobium campylopodum illustrating reaction to presence of parasite. 100x. 7. Cross-section of $\underline{C}$. decurrens with $\underline{A}$. campylopodum illustrating reaction to presence of parasite. 100X. H-host tree tissue; DM-parasite holdfast; m-meristematic zone of penetration structure; n-necrotic host tissue; wp-wound periderm of host. 


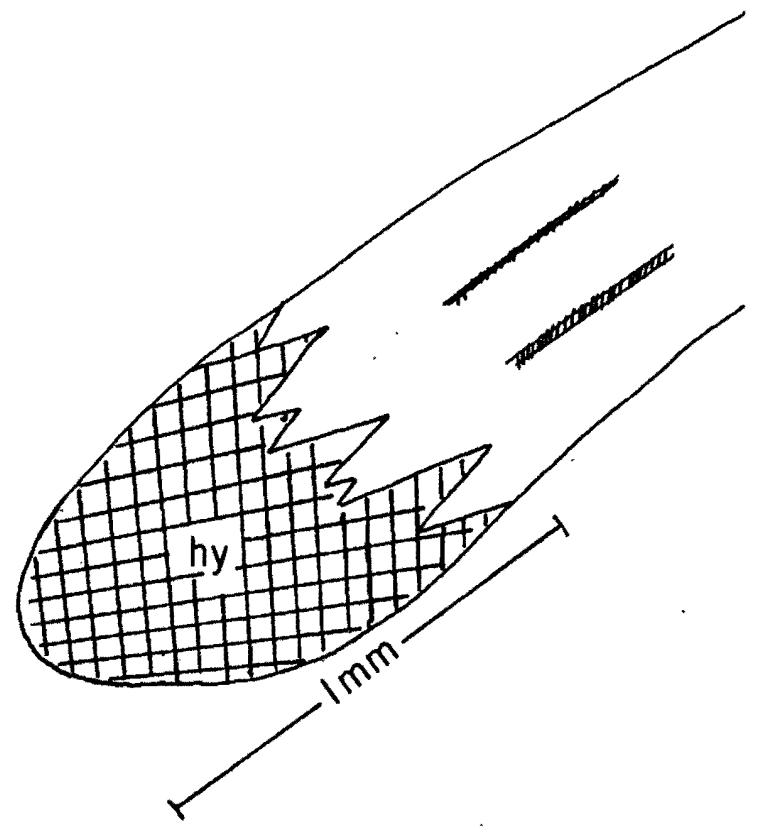

Figure 8. Diagram of a longitudinal section of a mistletoe radicle showing the location of hydrolases in parasite tissue. Hydrolases were seen in cross-hatched areas. hy-hydrolase. 